\title{
New Ideas of the Reform in the View of Globalization: Shanghai Pilot Free Trade Zone and One Belt and One Road
}

\author{
Weien Liang \\ Institute of Industrial Economics, Jinan University, Guangzhou, China \\ Email: liangenwei@163.com
}

Received 4 December 2015; accepted 26 December 2015; published 29 December 2015

Copyright (C) 2015 by author and Scientific Research Publishing Inc.

This work is licensed under the Creative Commons Attribution International License (CC BY).

http://creativecommons.org/licenses/by/4.0/

(c) (i) Open Access

\begin{abstract}
The appearance of Shanghai Free Trade Zone and One Belt and One Road strategy represents the continuous development of Chinese economic system reform. However, there are few essays about Shanghai Free Trade Zone and One Belt and One Road strategy and their relations. In terms of the successful experiences of the reform of Shanghai Free Trade Zone, this paper has manifested the strategic relationship of Shanghai Free Trade Zone and One Belt and One Road strategy. Actually, Shanghai Free Trade Zone and One Belt and One Road strategy is a very good combination strategy in development. And also in this paper, readers could find a new angle in understanding the developing Chinese economic system reform.
\end{abstract}

\section{Keywords}

One Belt and One Road, The Free Trade Zone, The Reform, Dividend of System Marketization

\section{Introduction}

When globalization enters in the new stage of resource integration, China is also in the key stage of the economic transformation and upgrading. Under the background of encouraging demands, Shanghai Pilot Free Trade Zone is established, which is the core part of the global strategy in China. The fundamental object of establishing Shanghai Pilot Free Trade Zone is to promote and deepen the reform, or its purpose is to find way of the reform for next ten years. Shanghai Pilot Free Trade Zone is upgrade of China’s special economic zones. 


\section{TPP and TIPP: Challenges and Opportunities Faced by China}

\subsection{Transformation of the Mode of Regional Cooperation and Creation of TPP and TTIP of New System of Global Trade}

Trans-Pacific Partnership Agreement (TPP) stems from Trans-Pacific Strategic Economic Partnership Agreement (P4), currently its member countries includes12 countries on Pacific Rim such as the United States, Australia, Japan, Malaysia, South Korea, Canada, etc. The agreement suggest US “return to Asia” strategy, which not only open up new space for American economy through regional cooperation, but also become a leader in the Asia-pacific region economic integration by taking concrete action, ensuring it can be access to these the most dynamic markets freely and fair.

On October 5, 2015, twelve negotiations of Trans-Pacific Partnership Agreement (TPP) reached a basic agreement on ministerial meeting held in Atlanta, Georgia in the United States, agreeing to free trade and forming the unity specification of a wide range of areas such as investment and intellectual property rights and so on. Meanwhile, Transatlantic Trade and Investment Partnership (TTIP) dominated by the United States is in talks. The aim of the agreement is to help Europe and the United States subjecting to the economic crisis and having difficulty in recovery make profit through the decline of regulatory costs between United States and Europe, simplified procedures, liberalization of Trade in services and public procurement. The United States implement their own trade rules in the TPP negotiations, or it will be an indicator for the future of the world. But if TTIP also dominated by the United States reached an agreement finally, the two super free trade area will put China into a passive situation immediately, perhaps to become passive recipients of the rules, because any regulations and technical standards adopted by the United States and Europe will likely become a reference of future bilateral, multilateral and regional trade negotiations, thus further consolidating its monopoly position and voice in the rule-making of global trade [1].

Free Trade Agreement (FTA) in general is the agreement reached on Trade liberalization and its related issues by the main body of independent tariff in voluntary way in order to avoid the difficulty of the WTO multilateral agreements, however, with the exception of negotiations in practice involving products and services. In the framework of new rules transparent, the negotiations of TPP will cover all products and services without exception, not only cancelling or reducing tariffs on goods, but also cover the safety standards, technical barriers to trade, animal and plant health inspection and quarantine, competition policy, intellectual property rights, government procurement, dispute settlement. The focus of the negotiations is the intellectual property rights, financial services, state-owned enterprises, environmental protection. Now the most desire for TTIP is weakening the non-tariff barriers, and setting unified regulatory standards. When the trade barriers between member states are reduced, external economies are the higher barriers, which will bring the effect of trade diversion. And it also means that China's exports will face the pressure of competition formed by members of the agreement. The pressure on the one hand is from the battle for markets in developed countries such as European Union and the United States, on the other hand is from the competition of industrial development in the developing countries by taking the advantages of the member states.

TPP and TTIP will create market access barrier defended by higher degree of liberalization. The two member countries of TTIP, the US and Europe, are two largest export market of China. TPP has absorbed the main members of both Asia Pacific economic cooperation organization and the association of southeast Asian nations, so major economies are absorbed into the two trade areas except China.

\subsection{Step-by-Step State of the US Global Strategy and Prisoner's Dilemma Faced by China}

The United States want to be the leader in the setting of international trade rules for future by setting high standards of rules, as well as reducing pressure by pushing transmission transformation and upgrade of domestic economy reversely. If TTIP is built, the global political layout of the US will be driven strongly by "one body two wings" strategy, in which the north American free trade area is body and the TPP and TTIP are two wings. Comprehensive intervention in the Asia-pacific region economic integration process through the TPP ensure the United States' geopolitical, economic and security interests, balance the China-ASEAN FTA, dilute the regional economic and political influence of big countries like China Japan and South Korea. Therefore, the United

States so can reshape and dominate the Asia-pacific regional economic integration process through its powerful political and military economic resources, then increase the influence of the United States in the Asia-pacific re- 
gion, implement America's global values at the same time with the exchange with government, enterprises and public communication.

If China join the TPP talks, possible adverse effects in the future include problems of state-owned enterprises, problems of the macroeconomic regulation and control, problems of marketization of exchange rate, all kinds of problems of creating fair competition environment for enterprises, problems of open up in financial, etc. TPP specifically established terms of the state-owned enterprises, requiring the principle of "competitive neutrality". The rule of origin of free trade requires zero-tariff between member countries, which bring huge bonuses to the manufacturing of southeast Asia, but put China's export products price in the low post and narrow its added value, because the products of China and southeast Asian countries have a great deal of homogeneity. Meanwhile, the condition of acquiring zero-tariff is to import raw materials from members of TPP, which cause companies of china facing dual squeeze from upstream and downstream market. The opening in financial establish a core of the financial system dominated by the dollar in order to guarantee the future dollar credit not collapse. Financial capital in these countries will be integrated deeply in the framework, the status of the dollar will be improved further, and the pace of yuan internationalization and China's financial and economic regionalization will be struggling [2].

Countries in the Asia-pacific region and the European Union countries have been catering to the United States, but clearly the United States reject China to join, there are some terms is against China. Even if china now join the TPP, China industry cannot afford to high standards of rules, but if not, it will be affected to get the qualification of voicing of international trade rules in the future for China, China is excluded in fact.

\subsection{China's Efforts to Adapt to the Situation of International Trade}

\subsubsection{Speeding up the Establishment of Shanghai Pilot Free Trade Zone}

The Establishment of Shanghai Pilot Free Trade Zone is not just the merger in geography of the bonded area, but also policy upgrade, in order to keep inclination to the new rules on the international market, then set an example for promoting it in the nation. Specifically, the first object of approving Shanghai Pilot Free Trade Zone is to transform government functions, reduce the micro intervention, change the investment system of investment and financing, and transform investment approval into investment regulation. Market-oriented reform is not only rely on policy dividends of the economic plan, but also release dividends of system to market stemming from getting rid of a slowing economy. At the same time, micro main body in the non-public economy should be strengthened, so as to break through the existing interests and break the unfair vested interests, fundamentally reform the single investment subject and the distortion situation of the investment and financing system, promote the marketization of land, labor, capital elements comprehensively basing on the core role of the reform of financial system, and so on [3]. In order to cope with the international new situation, countries and enterprises have to accept the higher criteria of free trade and free investment, including corporate social responsibility, sustainable development of environmental and energy, protection of intellectual property rights, etc. As we all know, it will have the effect of "inside the territory while outside the customs", by simplifying procedures and reducing the cost. For the most concerning problems of national treatmentstate-owned enterprise competitive neutrality before joining for TPP, in particular, the contents of the TPP negotiations should be brought into Shanghai Pilot Free Trade Zone: cancelling the limitation such as percentage of foreign equity in banking and insurance not exceed certain ratio, state-owned enterprises participating in the competition of the market by themselves. The industry not in the list of negative management can open from the establishment of enterprise to portfolio equity, and carry out foreign development and internal development to get the perfect combination of outside the customs and within the boundary

\subsubsection{Pushing Forward Negotiations of Free Trade Area Dominated by China Actively and Speeding up the Transformation of Substantial Cooperation Mode of Regional Economic and Trade with the East Asian Economies}

Now China is constructing 19 free trade areas with 32 countries and five continents. Fourteen agreements on free trade area have signed, involving 22 countries and regions. Moreover, China overtaken America and has been the largest trading partner to many nations. In 2011, China is the largest trading partner to 124 countries and the United States is the one for 76. China's vast market and potential spending power are enough to attract numerous countries to negotiate with China on free trade area, which break the blockade to China made by the 
US.

China needs to speed up the implementation of strategy of regional economic integration, adopts the divide and conquer strategy, and consolidate China's trade and economic cooperation with ASEAN, Chile, Australia and New Zealand, promoting substantial cooperation in key areas. China hopes to sign FTA with Japan and South Korea. China and South Korea Free Trade Agreement signed on June 1, 2015, which is the FTA signed by China covering most wide range of issues and involving the national biggest trading so far. China can focus on strengthening economic and trade relations with ASEAN and South Korea, leading Japan's free trade agreement negotiations with China, and through that accelerate the process of substantial regional economic and trade cooperation with East Asian economies [4].

\subsubsection{Making Preplan of Dealing with Trade Barriers in Labor Standards and Environmental Standards}

Both in multilateral and regional level, the negotiations on issues of Labor standards and green environmental standards will speed up. Such kind of problems actually is about how to solve the externality problem of environment in international trade. China should make her own preplans, formulating concrete measures. Future Chinese enterprises will face the impact of the Labor standards and environmental standards, by raising green component contained in export products to break up the foreign market access and increase market competitiveness of products, considering environmental protection when making enterprise management decision, enhancing international market competitiveness of products, and promoting the combination between cleaner production and structure upgrade in the industry. China should play a role in the setting of international labor standards and green environmental standards to on behalf of their own interests, otherwise will be in a passive situation.

\subsubsection{Participating in the TPP Negotiations Duly}

China can track closely the issues and processes of the TPP negotiations early, participating in the TPP negotiations in the right time according to the world economy, international politics and after weighing its overall interests. She participates in the negotiation by taking the position of attending or observers, considering to join the TPP or TTIP when necessary. And the key is to have the voice and power of rule-setting, not marginalized.

\subsubsection{Putting Forward and Accelerating Strategy of One Belt and One Road}

The idea of One Belt And One Road was put forward initiatively by President Xi Jinping during the period of visiting four central Asian states and the association of south-east Asian nations (ASEAN) in 2013. One Belt and One Road is the Abbreviation of "The Silk Road Economic Belt and the 21st Century Maritime Silk Road". The strategic concept based on inheritance and promotion of the ancient silk road, which including the construction of Silk Road Economic Belt and 21st-Century Maritime Silk Road. Firstly, One Belt And One Road run through the continents of Europe and Asia, linking the Asia-pacific economic circle to the European economic circle and radiating the development and cultivation of African economic circle in the view of regional scope. Secondly, from the perspective of regional development, it involves the regional integration related to our internal and external integration of Europe and Asia, as well as the connectivity and integration of both side. Finally, considering the cooperation content, it can drive all kinds of levels of integration and cooperation on every nation in the area in system of industry, trade, capital, talent, service, technical standards and military space [5].

\section{Tactical Implementation and Strategic Layout on Building of Shanghai Pilot Free Trade Zone and Strategy of One Belt and One Road}

Shanghai Pilot Free Trade Zone is attempting to appear in the form of free trade zone in one country, which adopts special regulatory policies and preferential taxation and will affect the policy of the reform in six fields, they are national financial, trade, shipping, administrative, investment and customs.

China has many special economic zones, and their main characteristic is the preferential policy enjoyed by enterprises in the area, including discount on land purchase fiscal support, tax breaks, etc. These policy differences form competitive advantage of inequality. Many scholars compared the establishment of Shanghai Pilot Free Trade Zone with that of Shenzhen Special Zone, but there is a profound difference in the background of the two zones. When reform and opening up, social capital is far from today's abundant amount, interests regime 
does not form and reform is advanced by relying on the powerful individual authority of leader. However, following the pace of democratization, leaders don't have the absolute authority at the time, but have to face of extremely complicated interest groups. The reform in more than 30 years ago is supported by all people, almost not having opposition. But today there are a lot of vested interests, who is not willing to reform. It can be said that Shanghai Pilot Free Trade Zone stress on "reform" rather than "policy", which produce the biggest significance that is to achieve economic growth through streamline administration and delegate power as a test of administrative system reform.

The mission of Shanghai Pilot Free Trade Zone is not a service for Shanghai, but makes a sample that can be copied and promoted basing on the construction of free trade zone, which need to three years to finish. As a result, their policies must have the vision. In other words, if a reform is difficult to promote in the future, its rationality will be doubt, and it will become another referential model of special zone and policy depression. Forced by the situation both at home and abroad, coming first is the principle of building of Shanghai Pilot Free Trade Zone, followed by argument. But what is certain is that the construction of Shanghai Pilot Free Trade Zone should not be taken as means for stimulating short-term economic growth. The ultimate goal is the national promotion, so as to promote China's long-term economic vitality. Since 2015, Fujian, Tianjin, Guangdong free trade zone were established. Demonstration effect of such policy for the central and western regions can be promoted from the following several aspects.

\subsection{Reform Existing Inefficient Situation and Release Vigor of Cities}

At present, the low efficiency of China's economic reform will be a new hope of future development. When China is going on rapid economic growth, the highly regulated economic model has led to a lot of wealth concentrated in the hands of a few privileged classes. In recent years, the contribution of non-public sectors of the economy like private enterprises, foreign-funded enterprises and so on to the economic growth has far more than the state-owned economy, but such resources like Banks' capital, the access and special quotas still focus on state-owned enterprises, which bring inefficient on the allocation of resources and cause economy lack of energy. Regime reform must be carried out to break the interests of the regime. However, there may be a certain vested interests standing behind every monopoly industry, the situation is extremely complex. There form has entered a "deep", which suggest that the reform reaches the inherent interests. Now reaching interests are often more difficult than reaching the soul. It is very quickly for Shanghai Pilot Free Trade Zone to get the approval and go to open up. The open up of Shanghai Pilot Free Trade Zone is before the third plenary session of the 18th, which had far-reaching significance of oat. Thus, the deeper purpose of setting up a free trade area is to promote the reform of the internal economic system and administrative management by deepening positive demonstration effect of the reform in the country and releasing dividend of system.

Currently, it is urgent for China to transform providing policy dividend into releasing the bonus of system. The beginning of the reform of should be the change of government functions. In past decade, the filed thought by many people of problems did not have big risk, instead the competitiveness was greatly enhance after these problems were solved, but those industries that were protected for a long time were more backward. That is because of too much government involvement in economic behavior, in other words, administrative power is ubiquitous in economy. When establish Shanghai Pilot Free Trade Zone, China should first reduce government intervention, relax the market, which will greatly promote the reform of China's system and the release of the dividend of system.

\subsection{To Gain Benefits from Prosperous Economic Hinterland and Systems Reform}

Shanghai is not far from Japan, Korea, the North Korea, Taiwan, Russia, Hong Kong, Guangdong province, etc. What is more, the Yangtze River goes across the mainland China and unlike Singapore which is a only transportation hub, Shanghai is more than a transportation port. Due to this, there are over several thousand foreign banks and millions of job opportunities. There is more development in Shanghai which is an economic hinterland. According to the recent data, we could find that provincial capitals and big cities are taking up the main development market share. The number of enterprises in secondary cities is reducing and their development is slowing down. Reforms should be done in a more balanced way. With the rapid development of economic centers, we need to allocate resources fairly in order to enhance the development of all regions, with which there are 
more chances and better development in more areas.

\subsection{To Revise the Lousy Market Order and Open up to Enhance Reform}

In the new Chinese opening-up and reform, to enhance the market systems and micro economic unit is a premise. Now, the biggest difficulty in China is the lousy order of investment subject, investment systems and factor market. More advanced international free trade and investment standards should be adopted, which include social responsibility of enterprise, sustainable development of environment and resources and intellectual property protection. Shanghai Free Trade Zone would be a test area for reform and open economy development, with the purpose of enhancing reform with opening-up. Trying to adapt to the new rules and open to the outside world is quite practical, with which to avoid the setback of people with vested interests. According to the present situation, the aim of setting up Shanghai Free Trade Zone is to change the current investment financing systems so as to transform the approval process management of foreign investment into Investment regulation. In brief, the main investors in China are the local governments and state-owned enterprises. Financing intermediary agent is mainly the bank. There is one important step in investment decision mechanism, namely, the approval and management of government. Actually, those state-owned enterprises and those investors with relationship with government would usually gain financial resources with low cost while those small and medium-sized private enterprises and start-ups would seldom get financial resources. In Shanghai Free Trade Zone, these imbalanced situations in investment system would turn into a better occasion. We need to focus on the reform on finance system and fully market those land factors, labor factors and capital factors.

\subsection{The Coming Breakthroughs of Gradual Reform of Financial Resources and to Enhance Marketization Mechanism}

In terms of financial reform, it is necessary to set up Shanghai Free Trade Zone. Especially in the aspect of currency exchange, it is of importance to choose appropriate places as controllable trial place. It is not feasible to promote currency across China without promoting it locally.

We cannot evaluate the potential impact on money value if there are radical changes. The success of financial trail place has great influence on the national policy, which include the all-round marketization of interest rate and the all-round opening of capital accounts. Marketization of interest rate is the premise of convertible capital items. Since currency convertibility is not available, this is a new try. Even though this new try succeeds, the extension work would be step by step. Shanghai Free Trade Zone could help the government with its economy without depending on the policy of finance and currency. Shanghai Free Trade Zone would be a trial area of convertible capital and accounts. With the setting up of related infrastructure, interest rate marketization and free convertibility of RMB would come into being. Government would encourage financing institution to offer RMB services and other financing services. Interest rates marketization would soon appear since loan rate in China has been lowered and Chinese government has been planning to build a long term saving insurance system.

At present, the biggest challenge is how to set up a effective finance border. Those enterprises which are not in the Shanghai Free Trade Zone cannot enjoy the tax preference and free convertibility of RMB. Besides, carry trade should be prevented by setting up a mechanism. The successful promotion of Shanghai Free Trade Zone is indispensable in the application of One Belt And One Road .To build up Shanghai Free Trade Zone is to put One Belt And One Road into practice. Moreover, One Belt and One Road strategy offer advanced standards for the policy and innovation exploration of Shanghai Free Trade Zone. With the great support of China's policy, the development and exploration of One Belt And One Road strategy and Shanghai Free Trade Zone would be greatly enhanced. And the past experiences with Chinese characteristics would also help the development of Shanghai Free Trade Zone and the other three free trade zones, with which the efficiency would be enhanced. There are well-developed social basis in China. This kind of combination model represents a brand new thinking of Chinese economic reform in the new international economic climate.

\section{Conclusion}

By sorting out the relations between Shanghai Free Trade Zone and One Belt and One Road strategy, this paper has offered plenty of experiences on economic development, reform of administration system and opening-up and reform, with which will promote the development of One Belt and One Road strategy. Later, the policy of 
Shanghai Free Trade Zone will get more flexible and more explorations will be done. The success of One Belt and One Road strategy will bring more activities in Chinese economic system reform. This paper offers a brandnew angle on regarding Chinese economic system reform and helps to better understand the strategic outline of Chinese economic reform.

\section{References}

[1] Li, C.G. (2013) New Trends of International Economic and Trade Rules. Journal of China Business Update, 1, 56.

[2] Meng, X and Song, M.L. (2012) The American TPP Strategy Analysis: Analysis of Economic Perspective. Journal of Asia-Pacific Economic Review, 6, 3-8.

[3] Chou, Y.P. and Xuan, C.Y. (2007) The Enlightenment of the Transformation in the Bonded Areas Based on the Development of the Foreign Free Trade Area. Journal of Yunnan Institute of Finance And Trade (Social Science Edition), $1,25-27$.

[4] Jia, G.Y. (2010) The Strategic Thinking of China’s Trade Development Based on China-ASEAN Free Trade Area. Journal of Business China, 3, 127.

[5] Jiang, R. (2015) To Explore "One Belt and One Road" with Shanghai as the Core Node and Other Nationally Strategic Integration Mechanism. Modern Economic Research, 4, 54-58. 